\title{
An Analysis of the Media Messages during the 2016 U.S. Presidential Election: A Thematic Comparison between CNN News and Donald Trump's Tweets
}

\author{
Zeinab Ghasemi Tari ${ }^{1} \&$ Zahra Emamzadeh ${ }^{2}$ \\ ${ }^{1}$ University of Tehran, Iran \\ ${ }^{2}$ University of Canterbury, New Zealand \\ Correspondence: Zeinab Ghasemi Tari, University of Tehran, Iran. E-mail: ghasemitari@ut.ac.ir
}

Received: March 26, 2018

Accepted: May 3, $2018 \quad$ Online Published: May 31, 2018

doi:10.5539/jpl.v11n2p78

URL: https://doi.org/10.5539/jpl.v11n2p78

\begin{abstract}
In the last presidential election of the United States (2016), the interaction between the Donald Trump and the American media was remarkable and unprecedented from both political and communication perspectives. The present paper is interested in observing the interactions between then the Republican Party candidate, Donald Trump, and the media of the United States. As there were major verbal confrontations between Trump, and some media, specifically CNN, this paper observes how Trump campaign reacted to CNN that turned out to be one of his biggest opponents. The relations and reactions are explained using "agenda setting" and "selective exposure" as theories and "thematic analysis" as the research methodology. The paper analyzes CNN videos from October 7 to October 31, and Trump's tweets during the same period. The reason for conducting the research during October is that this month is regarded as one of the most critical periods in US presidential election, known as "October surprise". Then a thematic analysis of the data is conducted to extract all accusations and allegations against Trump. Research results show that President Trump did not react to most of the accusations and attacks raised by CNN. Apparently Trump had decided that ignoring and not responding is a better strategy. There was an exception to this rule: Trump's treatment toward women. He did address that issue frequently and tried to justify himself and apologize. Accordingly, Trump's presidential campaign aim was to ignore accusations, keep attacking, and answering accusations only if they are already known to too many people.
\end{abstract}

Keywords: Trump, Twitter, CNN, media messages, thematic analysis, agenda setting, selective exposure

\section{Introduction}

Founded in 1980 by American media owner, Ted Turner, CNN is one of the most popular 24-hour cable news channels both inside the United States and around the world. It is believed that the news coverage of the first Persian Gulf of 1991 made the channel as the "big three" American networks beside Fox News and MSNBC (Ariens, 2017). Due to its significant effect on the audience the term "CNN effect" was coined after the news coverage of a series of important events including Tiananmen Square protests of 1989 and the fall of Communism, which brought images and conflicts to the public on one hand and had a major impact on countries' foreign policy on the other.

The CNN effect, which relates politics and international relations with communication and media studies, refers to the significant role $\mathrm{CNN}$, or any other 24-hour news channel, can play during important events through its "saturation coverage" (Gilboa, 2007, p. 7) CNN effect has been studied extensively from communication and international relations perspectives (Gurevitch, 1991; Floumoy, 1992; Parker, 1995; Volkmer, 1999; Silvia, 2001; Compaine, 2002' Bahador, 2007; Seol\& Namkoong, 2008). While the CNN effect refers to the role of media in foreign interventions and "humanitarian situations," the significant role of this news media in domestic politics should not be disregarded.

The CNN news coverage of the 2016 US presidential election made this news channel the most watched in its own history (Katz, 2016) and the third in total viewers with 788,000 for an increase of 25\% in 2016 (Otterson, 2017). However, the CNN campaign coverage of 2016 presidential election raised criticisms from Trump as well as his opponents. Aides to Republican candidates Jeb Bush, Ted Cruz and Marco Rubio accused Jeffrey A. Zucker, the CNN's president, of giving extensive coverage of Trump and undermining their candidates in the 
Republican primary (Grynbaum, 2016). On the other hand, on November 28, 2016, Donald Trump harshly criticized CNN by twitting "CNN is so embarrassed by their total (100\%) support of Hillary Clinton, and yet her loss in a landslide, that they don't know what to do." Meanwhile according to CNN Press Room report, despite increased tune-in during Trump's first month as President in February 2017, the news channel had its second-best February total day in ten years (since 2008) among adults 25-54 (cnnpressroom, 2018)

Beside the traditional media, the 2016 US presidential election witnessed the unprecedented role of the new social media and its significant impact. Currently, many politicians consider the new social media indispensable in their political success and have their own media advisors and strategists during their campaigns. Notably Twitter had 317 million monthly users in the third quarter of 2016. Donald Trump's constant use of Twitter and his ability to reach out to his audience through use of 140-character messages led to his eventual success. Significantly Trump used Twitter randomly, to attack the other side and his critics. It is believed that the nature of Twitter, its short and simplified content was appealing for the audience.

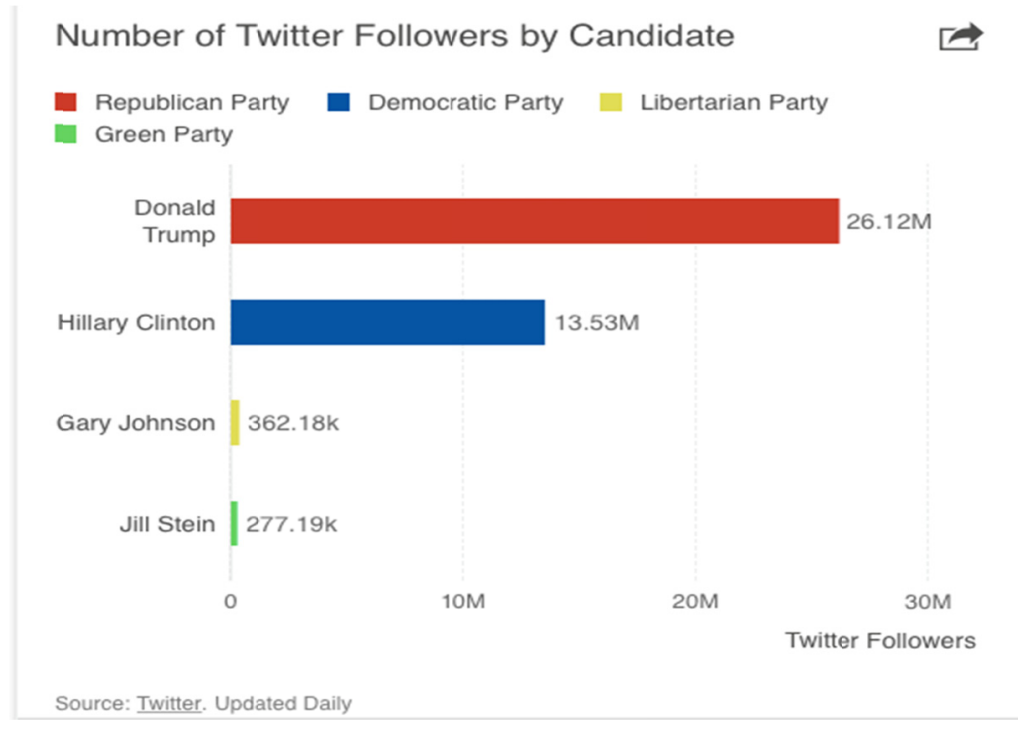

Figure 1. Twitter Updated Daily-November 19-2016

As of July 19, 2016, Hillary Clinton had 16,750,031 followers on Twitter with 9,887 tweets, while Donald Trump had 33,593,682 followers with 35,244 tweets.

Interestingly, according to Messing and Westwood there is an important distinction between traditional and modern social media landscape in two ways,

First, because these websites and mobile applications display content from different news providers in a single location, users no longer need to select a news source; instead they select the story itself. This represents a fundamental break from past modes of news consumption wherein people habituated themselves to a trusted source - instead social media users can select news from a wide range of sources deemed by friends or fellow internet users to be interesting or important (Messing \& Westwood, 2012, p. 3)

Studies and surveys have been conducted on the relation between US presidential election and Twitter. For instance, Shi and et al (2012) have considered millions of tweets aiming to predict the Republican presidential primaries. Wang et al. (2016) have considered the growth pattern of Donald Trump's followers in the every days of his campaign. Their analysis was focused on social demographics of the voters and their social status, gender and age. Bessi and Ferrara (2016) analyzed social media bots and their effects on 2016 US presidential election; in their view social media bots can effect political discussion negatively instead of improving it. Darwish and et al (2017) offered quantitative and qualitative analysis of top tweets of 2016 US presidential election on the day of the election.

The present study will offer an analysis of CNN videos from October 7 to October 31, and Trump's tweets during the same period. A thematic analysis of the data will be conducted to extract all accusations and allegations against Trump. The time period in which the paper is interested in is October, which is one of the most critical periods in US presidential election, known as "October surprise". Moreover, the timing is 
significant as the date for national election in the United States is in November and thus October events can have greater influence on the voters and consequently the outcome of the election. The reason for starting the analysis from October 7, is the published video and an article by the Washington Post in which, Trump was bragging to TV host Billy Bush about his attempts to seduce a married woman stating, "I don't even wait. And when you're a star, they let you do it, you can do anything...grab them by the pussy" (Fahrenthold, 2016, p. 5).

\section{Theoretical Framework}

Mass media are considered as major news outlets for the public to gain information about politics. The media can shape the public opinion both through publication and broadcasting news as well as deciding on the content, which is framed, filtered and disseminated. It is believed that the mass media have palpable and lasting effects on audiences, due to their prevalent flood of messages (Scheufele \& Tewksbury, 2007). Considering the theoretical framework, this section will briefly explain the three tenets of media's influence on the public mind, which includes, agenda setting (and framing as a part of agenda setting) and selective exposure.

"Agenda Setting" theory maintains that media have the power to set what people pay attention to (Rudd, 2016). The idea of an agenda-setting and the role of the press originates from Walter Lippmann's book Public Opinion (1922), with the first chapter entitled "The world outside and the pictures in our heads", but the theory was developed in the 1968 US presidential election by Max McCombs and Donald Shaw. According to the theory, media may not have absolute power in forcing people to think in a specific way but they can at least tell them what to think about (Cohen, 1963, p.13). According to Lang and Lang, "The mass media force attention to certain issues. They build up public images of political figures. They are constantly presenting objects suggesting what individuals in the mass should think about, know about, have feelings about" (as cited in Berelson \& Janowitz, 1966, p. 466).

A frame is the central organizing idea for making sense of events and suggesting what is at issue, "Framing is often considered as a necessary tool for reducing the complexity of an issue, given the constraints of their respective media related to news holes and airtime" (Gans, 1979, p. 12). Here gatekeepers paly an important role; gatekeeping is defined as, "the process of culling and crafting countless bits of information into the limited number of messages that reach people each day" (Shoemaker \& Vos, 2009, p.1). It refers to, "modes of presentations that journalists and other communicators use to present information in a way that resonates with existing underlying schemas among their audience (Shoemaker \& Reese., 1996, p.12). A gatekeeper is the one that decides about the dissemination of certain information. Significantly gatekeepers are able to control the public's knowledge about the actual events by letting some stories pass while blocking others, "The gatekeeper's choices are a complex web of influences, preferences, motives and common values" (Gupta, 2006, p.34).

Thus the media is capable of framing a topic by directing public attention on "key issues" through accentuating a topic in daily news, the opening story of newscasts, the time duration devoted to a topic, and repetition. Thus the media sets the agenda through patterns of coverage over a period of time by emphasizing on some issues and deemphasizing the others.

The question raised in this research is how agenda setting is related to electoral campaigns. Each presidential candidate, has his/her strengths and weaknesses. Accordingly, there are negative issues that the candidate can probably get away with and there would be issues that if getting public, the candidate would have a hard time convincing people. Here the theory of agenda setting becomes significant: it can be argued that the media sets the criterion for evaluation of a candidate. Thus in choosing a president should the voters focus on their financial success or their treatment of woman? Should the constituents think about their honesty or their experiences? Agenda Setting Theory says that media tell people what to think about and if true, then the media, which is more powerful would set the agenda of how and based on what criterion the voters should evaluate a presidential candidate.

However, many scholars believe that "agenda setting can no longer be understood as a monopoly of the mainstream media" (Boynton \& Richardson, 2015, p.1916) then the theory of "Selective Exposure" is raised. According to the theory of selective exposure, people are not passive recipients of media content. These scholars (Braun \& Clarke, 2008; Guest, MacQueen, \& Namey, 2012; Fereday \& Muir-Cochrane, 2006) argue that, in many cases people make a decision and then look for evidence to confirm their decision, rather than making a decision based on the existing evidence. A presidential campaign plan which bases its strategy on the idea that the audiences pick media that complies with their existing opinions is very different from the one who maintains that powerful media rule over the minds of people and sets the criterion for the constituencies to evaluate the candidates. If the audience cherry picks media and media content based on his existing tendencies then probably a candidate is not forced to react to any negative news or accusations made by an opponent media. For instance, 
when Donald Trump is accused of mistreating women, should he immediately respond to make sure his supporters would not get disappointed? If he or his advisors believe that many of his supporters are not even exposed to the negative news, then the right decision would be to remain silent. In fact, raising the issue can backfire, because many of his supporters or potential voters who do not follow opposing media may learn about the issue for the first time through his reaction.

Thus, "selective exposure" theory, does not consider media to be all-powerful. The reason is that the theory recognizes the similar power of the audiences: they can also pick and choose, and they choose a certain media over another and read or watch or listen to that certain media. Therefore, people are not totally passive recipients of media content. They choose the media on one hand and that media tells them what they should consider to be important through framing the issue.

The present research is an attempt to investigate which strategy was closer to Trump's strategy during the 2016 presidential election. Did he mainly try to address what he was accused of? If yes, was there a clear sequential relation between the accusations and the reactions? Meanwhile, it should be noted that the two candidates of 2016 US presidential election, were running very closely: in fact, Hillary Clinton had won the popular vote while Donald Trump gained the votes of the electoral collage. But important point in the current research is the success of Donald Trump campaign in general. Trump has been one of the most (if not the most) controversial presidential candidates in the history of the United States (Pfiffner, 2017) and he was accused of numerous wrongdoings. For him, it is probably a critical decision whether to react or ignore the accusations. Also knowing that Trump won the election, one would guess that he was quite successful in his campaign decisions. For this reason, considering his campaign strategy is of importance from both political and communicational perspectives.

\section{Methodology}

Numerous studies have been conducted on the interaction between media (both traditional media and social) and Donald Trump. These studies discuss how differently he acted toward traditional media and social media compared to other US presidential candidates. Alterman, believes that Donald Trump is the first president of the United States who has threaten American freedom of the press (Alterman, 2017, p. 68). The fact that his victory was a surprise for the United States is not something that can be ignored (Tracey , 2017, 526). Many scholars suggest that Trump's Twitter was one of the most important factors that led him to the office (Morris, 2017; Conway-Silva, Filer, Kensk, \& Tsetsi, 2017). It is noteworthy that there are many researches in the realm of social media and how it is changing the platform of the political communication. Gainous, for instance, argues how social media is being effective in US political campaign (Gainous \& Wagner, 2014).

Thematic analysis is about extracting key themes from the case that we want to study (Daly, Kellehear, \& Gliksman, 1997). It is a very common method used in qualitative studies (Crowe, Inder, \& Porter, 2015) to identify and analyze the meaning (Clarke \& Braun, 2017). Thematic analysis allows the researcher to look for patterns and themes and classify them. The method helps in identifying, analyzing and reporting themes within the corpus of data. It can also interpret various aspects of the research topic (Boyatzis, 1998). Thematic analysis helps the researcher in extraction of meanings from data and includes pinpointing, examining, and recording patterns or themes (Clarke, 2006). While the method is widely used in qualitative research, there is no clear agreement about what thematic analysis is and how to conduct a thematic analysis (see for instance (Attride-Stirling, 2001); (Boyatizis, 1998); (Tuckett, 2004). After the initial extraction of observed themes by the researchers, different techniques such as omitting, combining, and retitling of the concepts should be applied to arrive at an organized and meaningful set of themes.

In order to see if Trump's campaign policy was mainly reaction or ignoring the accusations raised against him, the researchers will analyze the messages published by Trump through his Twitter account on one hand, and a major opponent news channel i.e. CNN on the other hand. CNN was selected, as it was one of the major news channels inside the US, which covered 2016 presidential election and had a clear anti-Trump stance and continues to be one. We used thematic analysis to extract different themes including accusations, justifications and answers. In order to have a thematic analysis all videos related to 2016 US presidential election from October 7 to October 31 were watched and analyzed. Then a thematic analysis of the data was conducted to extract all accusations and allegations against Trump. On the other hand, Trump's Twitter account and his tweets from October 7 to October 31 were explored. The thematic analysis aimed to extract not only reactions or justifications but also his positive statements about being the better candidate for Presidency.

\section{Discussion and Findings}

Before analyzing the influence of the media on the audience, it should be noted that there are two approaches 
among the scholars in this regard. Those who believe in the absolute influence of the media on the audience (Cook,1983; Edwards \& Wood, 1999) and those who maintain that the media effect is not absolute and people are not passive recipients of media content (Wayne \& Joe, 1994; Walker, 1977). The latter argue that the effectiveness of media depends on numerous factors (Walgrave \& Van Aelst, 2006; Walgrave, Soroka, \& Nuytemans, 2008).

As mentioned thematic analysis CNN produced content on US 2016 Presidential election and Trump's twitter account from October 7 to October 31 was conducted. During this period Trump tweeted 431 tweets among which 116 tweets were announcements his campaign events, thanks messages as well as retweets (RTs) from other Twitter users.

By excluding those tweets 315 tweets where thematically analyzed. Trump's tweets can be thematically categorized as the following:

Trump is the next president of the United States; 2) The Media is dishonest; 3. CNN is a Fake News; 4) Trump will vanish terrorism; 5) Trump is the only solution for America; 6) America is in trouble; 7) Apologies and defending his behavior toward women; 8) Attacking Clinton over deletion of emails; 9) Clinton is a liar; 10) Clinton is financially corrupt; 11) Clinton can't do anything for America.

A thematic analysis of CNN's twenty-six program about Trump and US Presidential election reveals the following themes: 1) Trump is not as rich as he claims; 2) Trump mistreats women/he is misogynist; 3) Trump's brand is losing credibility; 4) Trump's words/behaviors have not changed in the past 27 years; 5) Trump is inexperienced and incompetent for US presidency; 6) Trump is racist; 7) Trump is unpredictable. 8) Trump has escaped paying taxes. 9) Trump has an unstable character.

The following table illustrates the media messages of the CNN and Trump's reactions toward them:

Table 1.

\begin{tabular}{|c|c|c|}
\hline \multirow{2}{*}{ Date } & $\mathrm{CNN}$ & Trump \\
\hline & Accusations & Answers and justifications \\
\hline 7-Oct & -Tape Scandal & 1. Apology for his behavior toward women \\
\hline 8 -Oct & $\begin{array}{l}\text {-Trump cannot recover } \\
\text { from Type Scandal }\end{array}$ & $\begin{array}{l}\text { 1. Trump is the next president 2. Media's failure to be honest in this } \\
\text { election } 3 \text {. Clinton is a "horrific" }\end{array}$ \\
\hline 9-Oct & $\begin{array}{l}\text {-The second presidential } \\
\text { debate }\end{array}$ & $\begin{array}{l}\text { 1. Trump is the next president 2. Clinton is corrupted person 3. I will } \\
\text { vanish terrorism } 4 \text {. Trump is the only solution for America 5. Failure } \\
\text { of Obama care } 6 \text {. Defending his behavior toward women } 7 \text {. Clinton's } \\
\text { email } 8 \text {. Clinton is a liar } 8 \text {. Clinton is financially corrupted person } 9 . \\
\text { Undermining Clinton } 10 \text {. Clinton can't do anything for America }\end{array}$ \\
\hline $10-$-Oct & $\begin{array}{l}\text {-Trump is behind Clinton } \\
\text {-Trump's poll denialism }\end{array}$ & 1. Media's failure to be honest in this election 2. $\mathrm{CNN}$ is dishonest \\
\hline $11-O c t$ & $\begin{array}{l}\text {-Trump is not that much } \\
\text { rich } \\
\text {-Trump targets Clinton's } \\
\text { health in new ad }\end{array}$ & $\begin{array}{l}\text { 1. Trump is the next president } \\
\text { 2. Clinton's email issue }\end{array}$ \\
\hline $12-\mathrm{Oct}$ & -Trump's treating women & $\begin{array}{l}\text { 1. Clinton can't do anything for America } \\
\text { 2. Media's failure to be honest in this election }\end{array}$ \\
\hline 13-Oct & $\begin{array}{l}\text {-Russia and Trump } \\
\text {-Trump Strategy toward } \\
\text { ISIS }\end{array}$ & 1. Trump is the next president \\
\hline 14-Oct & $\begin{array}{l}- \text { New sex assault } \\
\text { allegations }\end{array}$ & 1. Trump is the next president \\
\hline
\end{tabular}




\begin{tabular}{|c|c|c|}
\hline & $\begin{array}{l}\text {-Obama's response to } \\
\text { Trump }\end{array}$ & \\
\hline $15-O c t$ & $\begin{array}{l}\text {-Trump's "rigged" election } \\
\text { allegation } \\
\text {-Trump asks for drug test } \\
\text { from Clinton }\end{array}$ & $\begin{array}{l}\text { 1. Trump is the next president } 2 \text {. Media's faliure to be honest in this } \\
\text { election } 3 \text {. Clinton is a corrupted person } 4 \text {. Defending his behavior } \\
\text { toward women }\end{array}$ \\
\hline 16-Oct & $\begin{array}{l}\text {-Trump's treatment toward } \\
\text { women women -lack of } \\
\text { opening debate shake hand }\end{array}$ & $\begin{array}{l}\text { 1. Clinton is corrupted person } 2 \text {. Media's faliure to be honest in this } \\
\text { election } 3 \text {. Clinton is a corrupted person } 4 \text {. Undermining Clinton } 5 \text {. } \\
\text { Clinton's email } 6 \text {. Trump is the next president } 7 \text {. Clinton is financially } \\
\text { corrupted }\end{array}$ \\
\hline $17-$ Oct & $\begin{array}{l}\text {-US involvement in Syria } \\
\text { and Iraq and fighting with } \\
\text { ISIS }\end{array}$ & $\begin{array}{l}\text { 1. Failure of Obama care } 2 \text {. Trump is the next president } 3 \text {. Clinton's } \\
\text { email } 4 \text {. Media's failure to be honest this election } 5 \text {. Trump is the only } \\
\text { solution for America } 6 \text {. I will vanish terrorism } 7 \text {. Defending his } \\
\text { behavior toward women }\end{array}$ \\
\hline 18 -Oct & $\begin{array}{l}\text {-Melina Trump } \\
\text {-Pro-Trump tweets ware } \\
\text { produced by a bot } \\
\text {-Trump outspending } \\
\text { Clinton on TV ads }\end{array}$ & $\begin{array}{l}\text { 1. Clinton is corrupted person 2. Clinton's email } 3 \text {. Trump is the next } \\
\text { president } 4 \text {. Media's failure to be honest in this election } 5 \text {. Failure of } \\
\text { Obama care } 6 \text {. Undermining Clinton }\end{array}$ \\
\hline 19-Oct & $\begin{array}{l}\text {-Trump's brand loosing its } \\
\text { credibility } \\
\text {-Trump is inexperienced } \\
\text { person } \\
\text {-Trump's treating women } \\
\text { - Trump is racist }\end{array}$ & $\begin{array}{l}\text { 1. Failure of Obama care } 2 \text {. Trump is the only solution for America } 3 . \\
\text { Trump is the next president } 4 \text {. Clinton is a liar } 5 \text {. Clinton's email } 5 \text {. I } \\
\text { will vanish terrorism } 7 \text {. Clinton can't do anything for America } 8 . \\
\text { Clinton is financially corrupted }\end{array}$ \\
\hline 20-Oct & $\begin{array}{l}\text {-Trump's treatment toward } \\
\text { women } \\
\text {-Republicans slam Trump } \\
\text { on rigged election claim }\end{array}$ & $\begin{array}{l}\text { 1. Failure of Obama care } 2 \text {. Trump is the next president } 3 \text {. Clinton is } \\
\text { financially corrupted person }\end{array}$ \\
\hline 21-Oct & $\begin{array}{l}\text {-Trump is divisive for the } \\
\text { nation } \\
\text {-Trump has spent huge } \\
\text { amount of money for } \\
\text { campaigns }\end{array}$ & $\begin{array}{l}\text { 1. Clinton's email 2. Media's failure to be honest in this election } 3 \text {. } \\
\text { Clinton is financially corrupted person } 4 \text {. Trump is the next president }\end{array}$ \\
\hline 22-Oct & $\begin{array}{l}\text {-Trump's talk about } \\
\text { corruption of democrat } \\
\text { media } \\
\text {-Trump cast doubts about } \\
\text { the US institutions } \\
\text {-Trump wants to be } \\
\text { America's Czar }\end{array}$ & $\begin{array}{l}\text { 1. Clinton's email 2. Clinton is liar 3. Clinton is corrupted person } 4 . \\
\text { Trump is the only solution for America } 5 \text {. Trump is the next president } \\
\text { 6. Clinton can't do anything for America } 6 \text {. Clinton is financially } \\
\text { corrupted }\end{array}$ \\
\hline 23-Oct & $\begin{array}{l}\text {-Trump is racist } \\
\text {-Clinton a head of Trump }\end{array}$ & 1. Clinton is corrupted person \\
\hline
\end{tabular}


-Drain the swap message

ridiculed

-Clinton a head of Trump

-A trump win would sink

24-Oct stocks

1. Trump is the next president 2. Media's failure to be honest in this

-Trump will change

election 3. Undermining Clinton

relations with Cuba

-Trump is a bad person

25-Oct -Trump is racist

1. Failure of Obama care 2. Clinton is a corrupted person

- Trump tax escaping

-Trump's treating women

26-Oct -Trump escaping taxes

1. Failure of Obama care 2. Clinton is a liar

-Trump is very uninformed

- Trump's brand loosing its credibility

27-Oct

- Trump character is

changing

1. Trump is the next president 2. Clinton is corrupted person 3. I will vanish terrorism 4. Trump is the only solution for America 5. Failure of Obama care

\begin{tabular}{lll}
\hline \multirow{2}{*}{ 28-Oct } & -Trump tough path to the & 1. Trump is the only solution for America 2. Failure of Obama care 3. \\
& White House & Undermining Clinton 4. Clinton is a threat for America \\
\hline
\end{tabular}

-Trump and Clinton neck

in neck in polls

29-Oct -Trump's relation with

Russia

1. Failure of Obama care 2. Trump is the only solution for America 3. America is in the worst situation today 4. Trump's Hotel are popular

\begin{tabular}{lll}
\hline 30-Oct & $\begin{array}{l}\text {-Trump is blaming CNN, } \\
\text { Facebook, Google }\end{array}$ & $\begin{array}{l}\text { 1. Clinton is corrupted person } \\
\text { 2. US Media is biased }\end{array}$ \\
\hline \multirow{3}{3}{ 31-Oct } & $\begin{array}{l}\text {-Trump censures Obama's } \\
\text { foreign policy } \\
\text {-Trump's social policy is a } \\
\text { failure }\end{array}$ & 1. Failure of Obama care 2. Trump is the next president \\
\hline
\end{tabular}

A closer examination of Trump's Twitter content and the produced themes shows that Trump ignored many of the accusations such as those calling him inexperienced, racist, uninformed, financially and morally corrupted and etc. Instead of answering to those accusations he preferred to onset his counterattacks without directly addressing those allegations. His emphasized on the incompetency of Obama administration and with an extension that of Hillary Clinton's. He constantly referred to ObamaCare (23 tweets) as total "failure", and "disaster", or to Clinton's email controversy (13 tweets) or her financial dishonesty and the Clinton Foundation (8tweets) as a major scandal for her. In the same vein he did not answer to the accusations of racism and xenophobia, instead he tweeted about fighting with "Islamic Terrorism" and "Terrorist Immigrants". For instance when he was censured for his anti-immigrants stance, he tweeted, "Hillary has called for 550\% more Syrian immigrants, but won’t even mention "radical Islamic terrorists ((@realDonaldTrump, October 19).

However, he reacted directly to the tape scandal, which was deemed to impair a serious damage to his campaign. In fact mistreatment toward women is the only theme to which trump repeatedly reacted. He both defended his behavior toward women and apologized for it. For instance on October 9, he released a statement of apology, and at the same time tweeted on his Twitter account, "There's never been anyone more abusive to women in politics than Bill Clinton. My words were unfortunate-the Clintons' actions were far worse" (@realDonaldTrump) or on 
October 17, he accuse Obama's vice-president of sexual misbehavior "Watch Joe Biden's Long History Of Grabbing, Kissing and Groping Women Who Are Cringing" (@realDonaldTrump). When more allegations were raised against him on this regard he called the "phoney stories, 100\% made up by women" (@realDonaldTrump, Oct 17) and eventually dismissed the effect of the tapes and allegations by tweeting that his campaign is going on well and how media was deceiving the public through women with their "made-up stories and lies" (@realDonaldTrump, Oct 17). The researchers were unable to see a sequential pattern between attacks against Trump and reactions from his side. It is understandable though. Obviously, we do not have enough overlap between the themes. Apparently, Trump preferred to repeatedly attack rather than take a passive stance, answering allegations.

\section{Conclusion}

The paper started with an explanation about two possible strategies for a presidential campaign. It was argued that one of these strategies emphasizes on the media power and assumes the role of an "agenda-setter" for media. The other can be understood by through the theory of "selective exposure" which does not consider the public as passive recipients and that the audience selects and consumes a media content based on his political orientations and preferences.

The results show that President Trump did not react to most of the accusations and attacks by CNN. Instead countered the accusations by raising new accusations against both Obama and Hilary Clinton: he emphasized on public distrust on the media and Clinton's incompetency, corruption, lying and etc., projecting the allegations against himself to others. The only issue that compelled Trump to react was the tape scandal and other similar accusations about his relations toward women that were raised against him. He did address that issue frequently and tried to justify himself and apologize for it. According to selective exposure theory his reaction has a reasonable explanation: among many allegations and attacks against Trump's treatment toward woman was probably the one that was publicized the most. Even those media that had leaned toward Trump and had rather a supportive stance toward him, broadcasted this particular issue. The nature of the issue, which usually provokes people's curiosity and offends public opinion, persuaded Trump and his advisory team that the only way to prevent the failure of the campaign is addressing the issue by apologizing on one hand and projecting the allegations to his adversaries, on the other hand.

To sum up Trump's presidential campaign strategy was ignoring accusations, keep attacking, and answering accusations only if they were already known to too many people. In other words: react only the accusations that are already public information and are not limited to the audiences of a specific media.

At the end, the researchers acknowledge that the content produced by CNN and Trump's twitter accounts are not representative of all the media contents that were broadcasted during the 2016 US presidential campaign and this research is open to further investigations.

\section{Referrences}

Alterman, E. (2017). Challenging media: If his campaign is anything to go by, President Trump is likely to restrict freedom of the press. Index on Censorship, 68-69.

Ariens, C. (2017, September 27). TVNewser. Retrieved from Adweek: http://www.adweek.com/tvnewser/here-are-americas-most-watched-cable-networks/342950

Attride-Stirling, J. (2001). Thematic networks: an analytic tool for qualitative research. Qualitative Research, 385-405. https://doi.org/10.1177/146879410100100307

Berelson, B., \& Janowitz, M. (1976). Reader in public opinion and communication. New York: Free Press.

Bessi, A., \& Ferrara, E. (2016). Social bots distort the 2016 U.S. Presidential election online discussion. First Monday. https://doi.org/10.5210/fm.v21i11.7090

Boyatizis, R. E. (1998). Transforming Qualitative Information: Thematic Analysis and Code Development. Thousand Oaks: SAGE.

Boynton, G., \& Richardson, G. W. (2015). Agenda setting in the twenty-first century. New Media \& Society, 1916-1934.

Braun, V., \& Clarke, V. (2008). Using thematic analysis in psychology. Qualitative Research in Psychology, $77-101$

Clarke, V., \& Braun, V. (2017). Thematic analysis. The Journal of Positive Psychology, 297-298. https://doi.org/10.1080/17439760.2016.1262613 
$\begin{array}{lllll}\text { cnnpressroom. } & \text { (2018, } & \text { Feburary } & \text { 27). } & \text { Retrieved }\end{array}$ http:/cnnpressroom.blogs.cnn.com/2018/02/27/cnn-has-second-best-february-in-10-years/

Conway-Silva, B., Filer, C. R., Kensk, K., \& Tsetsi, E. (2017). Reassessing Twitter's AgendaBuilding Power: An Analysis of Intermedia Agenda-Setting Effects During the 2016 Presidential Primary Season. Social Science Computer Review, 1-15.

Cook, F., Tyler, T. R., Goetz, E. G., Gordon, M. T., Protess, D., Leff, D. R., \& Molotch, H. L. (1983). Media and Agenda Setting: Effects on the Public, Interest Group Leaders, Policy Makers, and Policy. The Public Opinion Quarterly, 16-35. https://doi.org/10.1086/268764

Crowe, M., Inder, M., \& Porter, R. (2015). Conducting qualitative research in mental health: Thematic and content analyses. Australian \& New Zealand Journal of Psychiatry, 616-623. https://doi.org/10.1177/0004867415582053

Daly, J., Kellehear , A., \& Gliksman, M. (1997). The public health researcher: A methodological approach. Melbourne, Australia: Oxford University Press.

Darwish, K., Magdy, W., \& Zanouda, T. (2017). Trump vs. Hillary: What Went Viral During the 2016 US Presidential Election. In International Conference on Social Informatics (pp. 143-161). Oxford: Springer, Cham. https://doi.org/10.1007/978-3-319-67217-5_10

Edwards, G. C., \& Wood, B. D. (1999). Who Influences Whom? The President, Congress, and the Media. The American Political Science Review, 327-344. https://doi.org/10.2307/2585399

Fahrenthold, D. A. (2016, October 8). Trump recorded having extremely lewd conversation about women in 2005. Retrieved

from https://www.washingtonpost.com/politics/trump-recorded-having-extremely-lewd-conversation-about-wom en-in-2005/2016/10/07/3b9ce776-8cb4-11e6-bf8a-3d26847eeed4_story.html?utm_term=.abec97916c07

Fereday, J., \& Muir-Cochrane, E. (2006). Demonstrating Rigor Using Thematic Analysis: A Hybrid Approach of Inductive and Deductive Coding and Theme Development. 80-92. https://doi.org/10.1177/160940690600500107

Gainous, J., \& Wagner, K. M. (2014). Tweeting to power: The social media revolution in American politics. New York: Oxford University Press.

Gans, H. J. (1979). Deciding what's news. New York: Pantheon Books.

Gilboa, E. (2007). The CNN Effect: The Search for a Communication Theory of International Relations. Political Communication, 27-44.

Grynbaum, M. M. (2016, December 1). CNN's Coverage of Trump Was Biased, Presidential Candidates'Aides Say. $\quad$ Retrieved from https://www.nytimes.com/2016/12/01/business/media/trump-cnns-coverage-biased-presidential-candidatesaides-say.html

Guest, G., MacQueen, K. M., \& Namey, E. E. (2012). Applied Thematic Analysis. London: Sage. https://doi.org/10.4135/9781483384436

Katz, A. (2016, December 28). TVNewser. Retrieved from http://www.adweek.com/tvnewser/2016-ratings-cnn-has-most-watched-year-ever/315014

Messing, S., \& Westwood, S. J. (2012). Selective Exposure in the Age of Social Media: Endorsements Trump Partisan Source Affiliation When Selecting News Online. Communication Research, 1042-1063.

Morris, D. S. (2017). Twitter Versus the Traditional Media. Social Science Computer Review, 1-13. https://doi.org/10.1177/0894439317721441

Otterson, J. (2017, June 27). Cable News Ratings: MSNBC, CNN, Fox News Post Double-Digit Growth in Q2. Retrieved from http://variety.com/2017/tv/news/cable-news-ratings-cnn-fox-news-msnbc-q2-1202479416/

Pfiffner, J. P. (2017). The Unusual Presidency of Donald Trump. Political Insight, 9-11. https://doi.org/10.1177/2041905817726890

Rudd, C. (2016). Effects of the Media on Citizens and Politicians. In G. Kemp, B. Bahador, K. McMillan, \& C. Rudd (Eds.), Politics and the Media (pp. 154-170). Auckland : Auckland University Press.

Shi, L., Agarwal, N., Agrawal, A., Garg, R., \& Spoelstra, J. (2012). Predicting US Primary Elections with Twitter. Retrieved from http://snap.stanford.edu/social2012/papers/shi.pdf 
Shoemaker, P. J., \& Reese., S. D. (1996). Mediating the message: theories of influences on mass media content. New York: Longman.

Tracey, S. (2017). Trust, Trump, and the Turnout: A Marketers Point of View. American Behavioral Scientist, 526-532. https://doi.org/10.1177/0002764217701218

Tuckett, A. G. (2004). Applying thematic analysis theory to practice: A researcher's experience. Contemporary Nurse, 75-87.

Volkmer, I. (1999). News in the Global Sphere: A Study of CNN and Its Impact on Global Communication. Luton: University of Luton Press.

Walgrave, S., \& Van Aelst, P. (2006). The Contingency of the Mass Media's Political Agenda Setting Power: Toward a Preliminary Theory. Journal of Communication, 88-109. https://doi.org/10.1111/j.1460-2466.2006.00005.x

Walgrave, S., Soroka, S., \& Nuytemans, M. (2008). The Mass Media's Political Agenda-Setting Power A Longitudinal Analysis of Media, Parliament, and Government in Belgium (1993 to 2000). Comparative Political Studies, 814-836. https://doi.org/10.1177/0010414006299098

Walker, J. L. (1977). Setting the Agenda in the U.S. Senate: A Theory of Problem Selection. British Journal of Political Science, 423-445. https://doi.org/10.1017/S0007123400001101

Wang, Y., Li, Y., \& Luo, J. (2016). Deciphering the 2016 U.S. Presidential Campaign in the Twitter Sphere: A Comparison of the Trumpists and Clintonists. In 10th International AAAI Conference on Web and Social Media (pp. 723-726). Cologne: AAAI Press.

Wayne, W., \& Joe, F. (1994). The President-news media relationship: A time series analysis of agenda-setting. Journal of Broadcasting \& Electronic Media, 437-449. https://doi.org/10.5210/fm.v21i11.7090

\section{Copyrights}

Copyright for this article is retained by the author(s), with first publication rights granted to the journal.

This is an open-access article distributed under the terms and conditions of the Creative Commons Attribution license (http://creativecommons.org/licenses/by/4.0/). 